\title{
Pre-operative stool analysis for intestinal parasites and fecal occult blood in patients with acute appendicitis
}

\author{
Sinan Hatipoğlu, M.D., ${ }^{1}$ Uğur Lök, M.D., ${ }^{2}$ Umut Gülaçtı, M.D., ${ }^{2}$ Tuncay Çelik, M.D. ${ }^{3}$
}

1'Department of General Surgery, Adıyaman University Faculty of Medicine, Adıyaman-Turkey

${ }^{2}$ Department of Emergency Medicine, Adıyaman University Faculty of Medicine, Adıyaman-Turkey

${ }^{3}$ Department of Parasitology, Adiyaman University Faculty of Medicine, Adıyaman-Turkey

\begin{abstract}
BACKGROUND: Etiology of acute appendicitis (AA) rarely involves parasitic infections of gastrointestinal (GI) tract. Preoperative diagnosis of parasitic infections in appendix remains difficult, although parasites can sometimes be observed inside the lumen during histopathological examination. The aim of the present study was to prospectively screen prevalence and species of intestinal parasites and adherence of fecal occult blood (FOB) in patients admitted to emergency department (ED) with clinical symptoms of AA who underwent appendectomy.
\end{abstract}

METHODS: Demographic and stool analysis data of a total of 136 patients ( $\geq 13$ years old) who underwent appendectomy between July 2009 and December 2014 were prospectively assessed, and histopathological data of all patients were retrospectively assessed.

RESULTS: In histopathological examination after appendectomy, of 136 patients, $75.5 \%(n=103)$ had AA, II.I\% ( $n=15)$ had perforated appendicitis (PA), and $13.2 \%(n=18)$ had a negative appendicitis (normal appendix, NA). Pre-operative stool analysis revealed that $25 \%(n=34)$ had intestinal parasites and $14.7 \%(n=20)$ of patients had positive fecal occult blood test (FOBT). Those with positive FOBT represented $9.7 \%(n=10)$ of 103 AA patients, $53.3 \%(n=8)$ of 15 PA patients, and II.I\% $(n=2)$ of 18 NA patients; this was statistically more significant for PA than other groups $(p<0.00 \mathrm{I})$.

CONCLUSION: Presence of intestinal parasites in stool might not be associated with appendicitis, but it can occasionally lead to pathological findings of appendicitis. A positive FOBT may be a predictor for PA.

Keywords: Appendicitis; fecal occult blood; intestinal parasites; stool analysis

\section{INTRODUCTION}

Acute appendicitis (AA) is an important cause of acute abdominal pain, and incidence of appendicitis in all age groups is $7 \%$. In addition, appendicitis is one of the most common surgical consultations in outpatient or emergency department (ED). ${ }^{[1]}$ Appendicitis is an emergency situation with highest unknown rate of etiological factors, even though clear diagnosis and treatment strategies have been established for more than 100 years. Etiology of appendicitis rarely involves

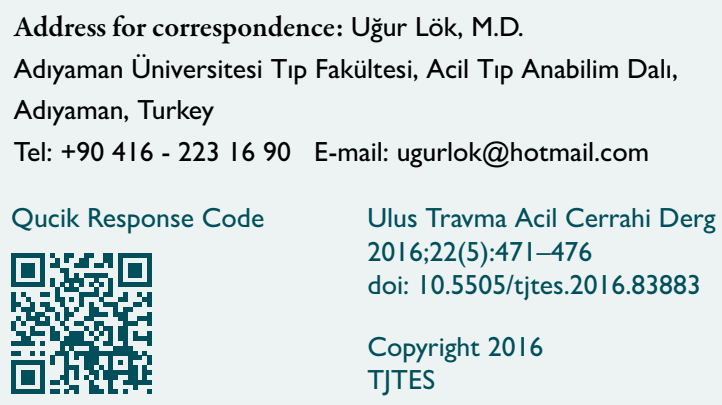

parasitic infections of gastrointestinal (Gl) tract in developed countries. ${ }^{[2]}$ Preoperative diagnosis of parasitic infections in appendix remains difficult, although parasites can sometimes be observed inside the lumen during histopathological examination.

Intestinal parasites cause significant morbidity and mortality worldwide. ${ }^{[3]}$ Parasites within resected appendix specimens are usually an incidental finding, but the relationship between parasites and appendicitis is unclear and remains controversial. Nevertheless, many parasites have been found in the lumen of normal appendix (NA). ${ }^{[4-7]}$ Intestinal parasites are rarely observed in relation to acute inflammation of appendix but can definitely be responsible for luminal obstruction leading to appendicitis. Ova release from female parasites may be a cause of appendiceal luminal obstruction, which consequently is followed by bacterial overgrowth, finally resulting in AA. ${ }^{[8]}$ Intestinal parasites, e.g., Enterobius vermicularis (most frequently), Ascaris lumbricoides, Schistosoma subspecies, Taenia subspecies, Trichuris trichuria, and Entamoeba histolytica, are among rare causes of appendicitis. ${ }^{[2,9-16]}$ 
However, to the best of our knowledge, while there are many studies investigating the etiology and diagnostic methods of $A A$, there are few prospective studies examining FOB and direct stool analysis for intestinal parasites in patients with pre-diagnosed AA. Most other studies have been performed postoperatively and retrospectively in appendectomy specimen. It is known that definitive diagnosis of AA is made histopathologically. If parasitic infection is proven to be an origin of appendicitis, it may be crucial from both cost effectiveness and public healthcare perspectives. Therefore, the aim of the present study was to investigate prospectively prevalence and species of intestinal parasites via stool analysis in patients with AA who were admitted to tertiary care in a rural city hospital ED and who underwent appendectomy.

\section{MATERIALS AND METHODS}

\section{Study Setting}

This study was conducted prospectively between July 2009 and December 2014 in the departments of academic emergency medicine and general surgery of a rural city tertiary care hospital at Adıaman University Faculty of Medicine. The study was approved by the university ethics committee. Verbal informed consent was obtained from each patient before study enrollment. Informed consent consisted of patient name, aim, and expected benefits of the study, and rights of patients during the study.

\section{Study Population}

A total of 136 patients over 13 years of age presenting consecutively to ED during the study period with appendicitis, diagnosed by clinical and laboratory methods, were included in scope of study. Patients presenting with parasitic or nonparasitic bowel disease in past medical history, those who did not want to participate in study, or who referred to ED outside of working hours, were excluded. Eligibility of patients for study was determined by an attending emergency physician and I general surgeon between 8:00 a.m. and 4:00 p.m.

Stool analysis, medical, and pathology records of all patients were evaluated in detail. Diagnosis of appendicitis or NA was made with perioperative macroscopic evaluation. Pathology department records about histopathological assessment of appendicitis specimens were reviewed for all patients retrospectively.

\section{Study Protocol}

Study data were prospectively collected by emergency physicians and the general surgeon. Demographic features of patients, physical examination findings, laboratory test results at ED presentation, complications that occurred during hospital admission, and final diagnosis and outcome of study patients were recorded on the study form. Diagnosis of AA was performed by the same attending emergency physicians and senior general surgeon. From each patient who was diagnosed with $\mathrm{AA}$ and ultimately underwent appendectomy, a stool sample was collected to analyze for parasites and FOB before surgery. All stool samples were rapidly analyzed (in I hour) in parasitology department of hospital between 8:00 a.m. and 4:00 p.m. Patients with intestinal parasites identified in stool analysis were directed to outpatient clinic for infectious diseases for medical treatment and follow-up after discharge.

Surgery was performed by same general surgeon who first examined participants. Preoperatively, patients received a prophylactic dose of second generation cephalosporin (1000 $\mathrm{mg}$ intravenously) and underwent open approach appendectomy via McBurney incision under general anesthesia. Laparoscopic approach was not performed for appendectomy due to technical inadequacy of institute. Abdominal exploration was performed in all patients with NA to exclude possible Meckel's diverticulum.

A negative appendectomy was defined as one performed due to clinical pre-diagnosis of AA but in which appendix tissue is found to be normal on routine histopathological examination.

\section{Laboratory Measurements}

A $9 \mathrm{~mL}$ sample of venous blood from antecubital area was obtained from each patient and stored in tubes for routine initial laboratory analysis. Stool sample from each patient was sent to parasitological laboratory inside a closed envelope and disposable, leak-proof, sealed container. Each stool sample was prepared with native-lugol and assessed by direct microscopy. Hemoglobin was screened in the feces using a guaiac-based technique. Entamoeba histolytica-specific antigen was investigated in diarrhea specimens using enzyme-linked immunosorbent assay (ELISA). Accepted stool specimens were studied by the laboratory without delay.

\section{Data Analysis}

All values were expressed as mean $\pm S D$ and percentage. To evaluate differences among groups, Pearson chi-square test was used. To analyze categorical data and frequency distribution, nonparametric chi square test was used. $P$ values $<0.05$ were considered statistically significant. Data were analyzed using SPSS software (version 17.0; SPSS Inc., Chicago, IL, USA).

\section{RESULTS}

A total of 136 patients pre-diagnosed with AA were admitted to ED during the study period. Of these patients, $61 \%$ $(n=83)$ were male and $39 \%(n=53)$ were female. Mean age was 24. $1 \pm 4.3$ years (range: $13-68$ years). Histopathological examination results were $75.7 \%(n=103)$ AA, II.I\% $(n=15)$ PA, and $13.2 \%(n=18)$ NA (Table I, Fig. I).

Stool analysis showed that 34 (25\%) cases had intestinal parasites. Of these 34 patients, incidence of intestinal parasites in 
Table I. Characteristics of patients with clinical symptoms of acute appendicitis

\begin{tabular}{lc}
\hline Patient, (male/female), (n) & $83 / 53$ \\
Mean age, years (min-max) & $24.1 \pm 4.3(13-68)$ \\
Acute appendicitis $(\mathrm{n})$ & 103 \\
Perforated appendicitis $(\mathrm{n})$ & 15 \\
Normal appendix ( $\mathrm{n})$ & 18 \\
Intestinal parasites ( $\mathrm{n})$ & 34 \\
Positive fecal occult blood $(\mathrm{n})$ & \\
$\quad$ Acute appendicitis & 10 \\
$\quad$ Perforated appendicitis & 8 \\
$\quad$ Normal appendix & 2 \\
Patients with diarrhea $(\mathrm{n})$ & 12 \\
\hline
\end{tabular}

stool samples was 13 (38.2\%) Giardia intestinalis, 8 (23.5\%) Blastocystis hominis, 6 (17. 6\%) Entamoeba coli, 2 (5.9\%) lodamoeba butschlii and I (2.9\%) mature Taenia subspecies ring. Of the patients, 2 (5.9\%) cases contained both Giardia intestinalis and Blastocystis hominis, and I (2.9\%) case contained both Blastocystis hominis and Entamoeba coli. Only I $(2.9 \%)$ case was positive in present study out of a total of 12 (8.8\%) patients with diarrhea analyzed with ELISA technique for specific antigens for Entamoeba histolytica (Table 2, Fig. 1). The most prevalent intestinal parasite in stool analysis was Giardia intestinalis, and this result was statistically significant $(p<0.001)$. Pathological examination of appendectomy specimens showed that only 2 ( $1.47 \%)$ cases contained parasites (I Enterobius vermicularis, I Taenia subspecies). The patient with Taenia subspecies in appendectomy specimen also exhibited same parasite in preoperatively collected stool sample, but patient with Enterobius vermicularis in ap-

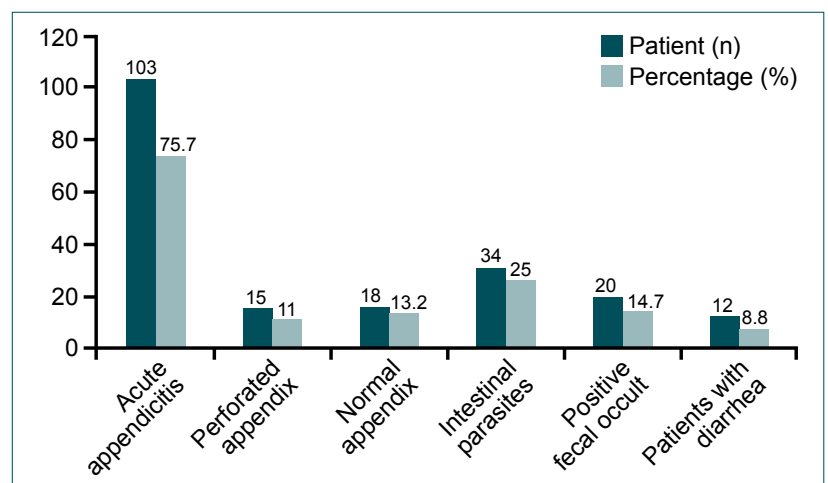

Figure 1. Characteristics of patients.

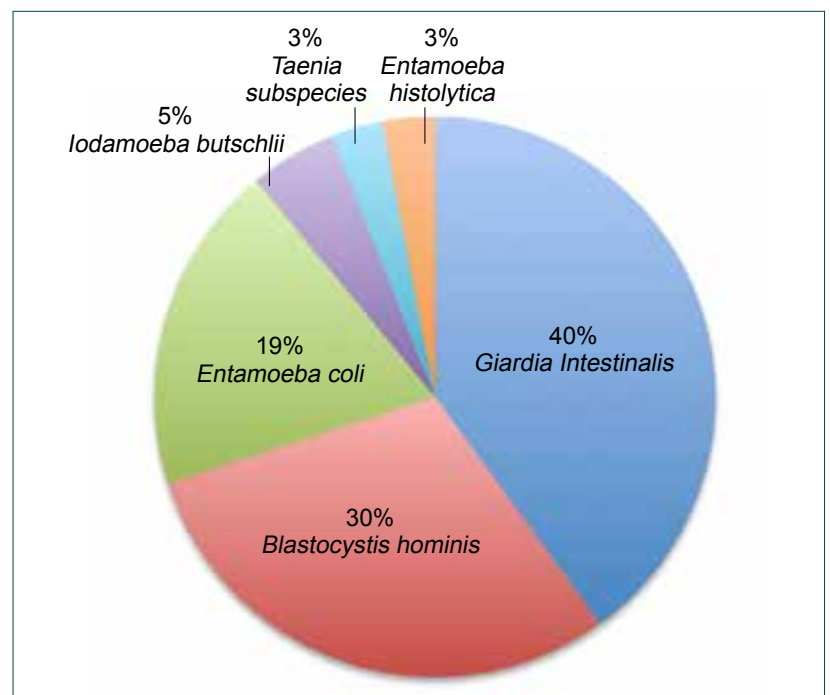

Figure 2. Shows ratios and species of the intestinal parasites that obtained from pre-operative stool samples.

pendectomy specimen did not exhibit any parasite in stool sample.

Table 2. Shows number and species of the intestinal parasites with clinical symptoms of acute appendicitis obtained from pre-operative stool samples

\begin{tabular}{llcc}
\hline Parasites & \multicolumn{2}{c}{ Frequency $(\mathbf{n}=34)$} & p \\
\cline { 2 - 3 } & $\mathbf{n}$ & $\%$ & $<0.00$ I \\
\hline Giardia intestinalis & 13 & 38.2 & 23.5 \\
Blastocystis hominis & 8 & 17.6 \\
Entamoeba coli & 6 & 5.9 \\
lodamoeba butschlii & 2 & 2.9 \\
Taenia subspecies & $\mathrm{I}$ & 2.9 \\
Entamoeba histolytica & $\mathrm{I}$ & 5.9 \\
Giardia intestinalis and Blastocystis hominis & 2 & 2.9 \\
Blastocystis hominis and Entamoeba coli. & $\mathrm{I}$ &
\end{tabular}

$34(25 \%)$ of cases had intestinal parasites. Of these 34 patients, the incidence of intestinal parasites in stool samples was 13 (Giardia Intestinalis, 8 Blastocystis hominis, Entamoeba coli, lodamoeba butschlii and mature Taenia subspecies (spp.) ring. Of the patients, cases contained both Giardia intestinalis and Blastocystis hominis, and I (2.9\%) case contained both Blastocystis hominis and Entamoeba coli. 
Table 3. Shows fecal occult blood test ratios of operated patients with clinical symptoms of acute appendicitis

\begin{tabular}{|c|c|c|c|c|c|c|c|}
\hline & \multicolumn{4}{|c|}{ Fecal occult blood test } & \multicolumn{2}{|c|}{ Total $(n=136)$} & \multirow[t]{3}{*}{$\mathbf{p}$} \\
\hline & \multicolumn{2}{|c|}{ Negative } & \multicolumn{2}{|c|}{ Positive } & \multirow[b]{2}{*}{$\mathbf{n}$} & \multirow[b]{2}{*}{$\%$} & \\
\hline & $\mathbf{n}$ & $\%$ & $\mathbf{n}$ & $\%$ & & & \\
\hline Acute appendicitis & 93 & 90.2 & 10 & 9.7 & 103 & 75.7 & \\
\hline Perforated appendicitis & 7 & 46.7 & 8 & 53.3 & 15 & II.I & $<0.001$ \\
\hline Normal appendix & 16 & 88.9 & 2 & II.I & 18 & 13.2 & \\
\hline
\end{tabular}

Stool analysis also revealed that $14.7 \%(n=20)$ of patients had positive FOBT. Those with positive FOBT represented $9.7 \%$ $(n=10)$ of 103 patients with AA, $53.3(n=8)$ of 15 patients with PA, and $11.1 \%(n=2)$ of 18 patients with NA, and this was statistically more significant for PA than other groups $(p<0.001)$ (Table 3).

\section{DISCUSSION}

Parasitic diseases of $\mathrm{Gl}$ tract affect more than half of the world population. While they are mainly observed in tropical countries, they have begun to become an important health problem in developing countries due to climatic conditions, excessive population growth, low level of education, failure to observe personal hygiene, inadequate and/or contaminated water sources, lack of infrastructure, increasing migration,

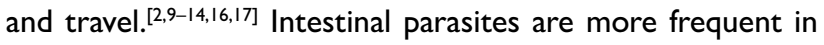
rural territories than urban cities. ${ }^{[17]}$ Training and hygiene are very important for protection from infections that spread by fecal-oral route.

Primary pathogenic event in majority of patients with AA is believed to be luminal obstruction. This event may result from a variety of causes, which include fecaliths, lymphoid hyperplasia, vegetable matter and fruit seeds, foreign bodies, intestinal parasites, barium from previous radiographic studies, and both primary (carcinoid, adenocarcinoma, Kaposi sarcoma, and lymphoma) and metastatic (colon and breast) tumors. ${ }^{[13,16,18]}$ Lymphoid hyperplasia and fecaliths are the most frequently observed etiologies of luminal obstruction. ${ }^{[19]}$

There is little evidence regarding the relationship between parasites and AA. ${ }^{[13]}$ Presence of parasites in appendix may cause appendicitis, explained by hypothesis of appendiceal lumen obstruction. However, parasites can lead to $A A$, as do bacteria and viruses. According to the literature, parasitic infections such as enterobiasis, ${ }^{[5,6]}$ taeniasis, ${ }^{[12,20-22]}$ and ascariasis, ${ }^{[15,23]}$ which are among the less frequent factors, have been observed in patients with AA. Geographic location and social situations lead to prominent variations in prevalence of parasites. Another factor in prevalence of parasites might be existence of minimal differentiations in techniques followed by pathologists. ${ }^{[5]}$
In the present study, we observed that 34 patients had intestinal parasites. Most frequent parasite found was Giardia intestinalis, but only 2 parasites (I Enterobius vermicularis and I Taenia subspecies) were obtained in appendectomy specimens. In patients undergoing or planning surgical treatment due to AA, evaluation for intestinal parasites is important and may aid in both etiological and medical treatment of these patients. In most cases, same intestinal parasites were not obtained in histopathological examination of appendicitis specimen and in patient pre-operative stool sample. For this reason, variety and frequency of parasites did not correlate with appendicitis specimen in current study, and it may be concluded that there is not any risk for AA caused by parasites obtained from stool samples. Diagnosis of parasitic infestation is generally achieved only after pathological examination of resected appendix. Only 2 of the AA patients had intestinal parasites observable in appendectomy specimens. Taenia subspecies was also obtained from pre-operative stool sample of patient whose appendectomy specimen showed that parasite; however, Enterobius vermicularis was not observed in stool sample of second patient taken before surgery.

Enterobius vermicularis is observed commonly in Gl tract worldwide, and is considered to be the most common parasitic infection that may cause ileocolitis, enterocutaneous fistulas, urinary tract infections, mesenteric abscesses, salpingitis, and appendicitis (lymphoid hyperplasia to acute phlegmonous appendicitis, gangrenous appendicitis and peritonitis). Mature form of Enterobius vermicularis is most frequently observed in proximal section of ascending colon, cecum, appendix, and terminal ileum. ${ }^{[6,8,11,16]}$ The link between Enterobius vermicularis and appendicitis was first determined in 1899 , and incidence of Enterobius vermicularis in patients with symptoms of AA ranges from $0.2-41.8 \% .^{[2,5-8,11,15,24,25]}$ This infection is observed in all ages and socio-economic levels, and diagnosis may be determined by direct visualization of adult worms or microscopic detection of eggs, but only minorities of patients have eggs in their stool. ${ }^{[8]}$ Enterobius vermicularis wanders widely inside the bowel, including appendix. Diagnosis of Enterobius vermicularis can be made using cellophane tape test, and treatment includes mebendazole and household sanitation. ${ }^{[7]}$ In present study, we observed only I case of En- 
terobius vermicularis. This result was compatible with literature data but lower than expected. Cellophane tape test for diagnosis of Enterobius vermicularis could not be performed.

Taeniasis in appendix is very rare, and there are few case reports about it in the literature. ${ }^{[8,21]}$ Entry of Taenia subspecies into appendix remains an unsolved issue. Taeniasis is a well-known parasitic infection characterized by presence of Taenia saginata or Taenia solium in human intestines, and it occurs as result of consuming raw or undercooked meat. It is identified when segments of the parasite appear in stool or exit through anus. ${ }^{[8,10-12,16,21]}$ In present study, eggs of Taenia subspecies were observed in I appendectomy specimen and I stool sample, although adult form of the parasite was not observed, and case was not specified as Taenia saginata or Taenia solium. Clinical symptoms of taeniasis are bowel irritation, abdominal pain, and diarrhea, and they may rarely lead to appendicitis or cholangitis. ${ }^{[16,26]}$ The first sign of Taenia subspecies infection is usually a segment of parasite observed in stool by microscopy, and this infection of appendix is so rare that situation invites a case report. ${ }^{[1,20-22]}$ Identification of specific species is not required in patients with taeniasis, and single dose of praziquantel or albendazole treatment can efficiently clear the infection following surgery. ${ }^{[1,16,17,20-22]}$

Observation of intraluminal intestinal parasites within resected appendectomy specimen is generally an incidental finding, and roles of these parasites in AA have been discussed. Most parasitic appendix infestations are not associated with acute inflammation and are thus considered a component of false appendicitis. Intestinal parasites are commonly found within a non-inflamed appendix, and in some retrospective studies, they constitute only a minor percentage of negative appendectomies. ${ }^{[8]}$ In the present study, low incidence of parasites among appendectomy specimens (1.47\%) and failure to demonstrate a relationship with all events derived from appendicitis do not support hypothesis that intestinal parasites in stool analysis are a major cause of appendicitis. Parasites are rarely found in appendix, and their presence in stool analysis is very rarely associated with appendicitis.

General surgeons should be aware that clinical management of such cases is different from management of non-parasitic appendicitis. Excisional appendectomy materials should be examined for fecaloid material, parasite eggs or intestinal parasite itself that might be within. Appendectomy treats only the symptoms and not the primary cause of the disease. Additionally, in acute appendicitis cases with parasitic infection, patient should receive post-operative anti-parasitic medical treatment to prevent possible re-infection. Moreover, family members should receive anthelmintic treatment to eliminate asymptomatic reservoirs and eradicate infections.

FOB is defined as very small amounts of blood that may normally be lost from stomach or throughout the intestinal tract during digestion that are not detectable on gross inspection, usually less than $50 \mathrm{mg}$ of hemoglobin $(\mathrm{Hg})$ per gram of stool. Increased amounts are associated with a variety of benign and malignant gastrointestinal diseases, especially colonic neoplasm, and tests are most often used to screen patients for such lesions. FOBT is based on detection of $\mathrm{Hg}$ in $\mathrm{fe}-$ ces using guaiac-based technique, and newer technology and highly sensitive fecal immunochemical tests have also proved effective in screening for most common colorectal cancer. ${ }^{[27]}$ No previous study in the literature investigating combination of appendicitis and FOBT has been located by current study authors as yet. It was current study finding that $14.7 \%$ of patients had positive FOBT, 53.3\% of whom had PA. In PA cases, positive FOBT was statistically significant. This conduction may be explained by severe and long-term peri-appendicular colonic mucosal and sub-mucosal inflammation, with desquamation leading to mucosal hemorrhage.

\section{Limitations}

Due to lack of patient compatibility and need for urgent operation, we could not use cellophane tape test for diagnosis of Enterebius vermicularis. Therefore, Enterebius vermicularis could not be discussed in this paper. Second, because intestinal parasites show presentation and frequency variation regionally in different age groups, there has not been any previous study investigating prevalence of intestinal parasites in authors' region. Therefore, we could not compare AA cases with normal population prevalence. Third, stool analyses were performed during office hours because laboratory at study institution is open only at those times. Finally, relationship between positive FOBT and presence of intestinal parasites was not evaluated.

\section{Conclusion}

Parasites are rarely found in the appendix, and their presence in stool analysis is very rarely associated with appendicitis. Appendectomy is not sufficient for curative treatment in parasitic infections with appendicitis. Medical treatment should also be administered after appendectomy. Intestinal parasites within resected appendix specimens are generally an incidental finding. Even if general surgeon does not observe inflamed appendix in course of operation, intestinal parasites should be considered an etiological factor for AA, especially in countries where intestinal parasites are endemic. Rapid screening of stool specimens by an experienced pathologist may be useful. A positive FOBT may be predictor for PA. Present study authors also believe that more comprehensive, randomized studies are needed to support our current findings.

Conflict of interest: None declared.

\section{REFERENCES}

1. Hatipoglu S, Hatipoglu F, Abdullayev R. Acute right lower abdominal pain in women of reproductive age: clinical clues. World J Gastroenterol 2014;20:4043-9. Crossref 
2. da Silva DF, da Silva RJ, da Silva MG, Sartorelli AC, Rodrigues MA. Parasitic infection of the appendix as a cause of acute appendicitis. Parasitol Res 2007;102:99-102. Crossref

3. Ozcelik S, Sumer Z, Celiksoz A, Poyraz O, Koçoglu F, Demirtas S, et al. Survey of intestinal parasites in orphan of orphnage in Sivas, Turkey. Turkiye Parazitol Derg. 1995;19:257-9.

4. Dorfman S, Talbot IC, Torres R, Cardozo J, Sanchez M. Parasitic infestation in acute appendicitis. Ann Trop Med Parasitol 1995;89:99-101.

5. Gialamas E, Papavramidis T, Michalopoulos N, Karayannopoulou G, Cheva A, Vasilaki O, et al. Enterobius vermicularis: a rare cause of appendicitis. Turkiye Parazitol Derg 2012;36:37-40. Crossref

6. Sodergren MH, Jethwa P, Wilkinson S, Kerwat R. Presenting features of Enterobius vermicularis in the vermiform appendix. Scand J Gastroenterol 2009;44:457-61. Crossref

7. Kucik CJ, Martin GL, Sortor BV. Common intestinal parasites. Am Fam Physician 2004;69:1161-8.

8. Aydin O. Incidental parasitic infestations in surgically removed appendices: a retrospective analysis. Diagn Pathol 2007;2:16. Crossref

9. Thanikachalam MP, Kasemsuk Y, Mak JW, Sharifah Emilia TS, Kandasamy P. A study of parasitic infections in the luminal contents and tissue sections of appendix specimens. Trop Biomed 2008;25:166-72.

10. Meamar AR, Ahady N, Falakimoghaddam MH, Safari MR, Kia EB. Concomittant infection of appendix with Taenia and Enterobius vermicularis. J Med Sci 2006;6: 38-40. Crossref

11. Lejbkowicz F, Abel AB, Tsilman B, Cohen HI. Taenia infestation in the appendix: a report of two cases. J Med Microbiol 2002;51:90-1. Crossref

12. Sartorelli AC, da Silva MG, Rodrigues MA, da Silva RJ. Appendiceal taeniasis presenting like acute appendicitis. Parasitol Res 2005;97:171-2.

13. Wani I, Maqbool M, Amin A, Shah F, Keema A, Singh J, et al. Appendiceal ascariasis in children. Ann Saudi Med 2010;30:63-6.

14. Madavo C, Hurriez H. Schistosomiasis of the appendix. J R Soc Med 2006;99:473-4. Crossref

15. Sah SP, Bhadani PP. Enterobius vermicularis causing symptoms of ap- pendicitis in Nepal. Trop Doct 2006;36:160-2. Crossref

16. Ilhan E, Senlikci A, Kizanoglu H, Ustüner MA, Vardar E, Aykas A, et al. Do intestinal parasitic infestations in patients with clinically acute appendicitis increase the rate of negative laparotomy? Analysis of 3863 cases from Turkey. Prz Gastroenterol 2013;8:366-9. Crossref

17. Ulukanligil M, Seyrek A. Demographic and parasitic infection status of schoolchildren and sanitary conditions of schools in Sanliurfa, Turkey. BMC Public Health 2003;3:29. Crossref

18. Prystowsky JB, Pugh CM, Nagle AP. Acute appendicitis. Curr Probl Surg 2005;42:688-92. Crossref

19. Freeman HJ. Spontaneous free perforation of the small intestine in Crohn's disease. Can J Gastroenterol 2002;16:23-7. Crossref

20. Dorfman S, Cardozo J, Dorfman D, Del Villar A. The role of parasites in acute appendicitis of pediatric patients. Invest Clin 2003;44:337-40.

21. Hafezi Ahmadi M, Seifmanesh $H$. Taeniasis caused appendicitis without local tenderness: A rare case. Hospital Chronicles 2011;6:207-9.

22. Ajmera RK, Simon GL. Appendicitis associated with Taenia species: cause or coincidental? Vector Borne Zoonotic Dis 2010;10:321-2.

23. Sforza M, Andjelkov K, Zaccheddu R, Ivanov D, Krstić S, Paganelli A. An unusual case of ascariasis of the appendix. Srp Arh Celok Lek 2011;139:809-11. Crossref

24. Arca MJ, Gates RL, Groner JI, Hammond S, Caniano DA. Clinical manifestations of appendiceal pinworms in children: an institutional experience and a review of the literature. Pediatr Surg Int 2004;20:372-5.

25. Saxena AK, Springer A, Tsokas J, Willital GH: Laparoscopic appendectomy in children with enterobiusvermicularis. Surg Laparosc Endosc Percutan Tech 2001;11:284-6. Crossref

26. Kia EB, Afshar-Moghadam N, Kazemzade H. Appendicular taeniasis: association with acute gangrene appendicitis in Isfahan, Iran. South Asian J Trop Med Public Health 2004;35:259-61.

27. Young GP, Symonds EL, Allison JE, Cole SR, Fraser CG, Halloran SP, et al. Advances in Fecal Occult Blood Tests: the FIT revolution. Dig Dis Sci 2015;60:609-22. Crossref

\title{
ORIJIINAL ÇALIŞMA - ÖZET
}

\section{Akut apandisit hastalarında gaitada gizli kan ve intestinal parazitler için ameliyat öncesi gaita analizi \\ Dr. Sinan Hatipoğlu, ${ }^{1}$ Dr. Uğur Lök, ${ }^{2}$ Dr. Umut Gülaçtı, ${ }^{2}$ Dr. Tuncay Çelik ${ }^{3}$}

\author{
${ }^{1}$ Adıyaman Üniversitesi Tıp Fakültesi, Genel Cerrahi Anabilim Dalı, Adıyaman \\ ${ }^{2}$ Adıyaman Üniversitesi Tıp Fakültesi, Acil Tıp Anabilim Dalı, Adıyaman
}

${ }^{3}$ Adıyaman Üniversitesi Tıp Fakültesi, Parazitoloji Anabilim Dalı, Adıyaman

AMAÇ: Akut apandisitin etiyolojisi nadir olarak gastrointesitinal sistemin parazitik enfeksiyonlarını içermektedir. Parazitler bazen histopatolojik inceleme sırasında lümen içinde gözlemlenebilmesine rağmen ameliyat öncesi tanısı zor bir durum olarak kalmaya devam etmektedir. Bu çalışmanın amacı, akut apandisitin klinik semptomları ile acil servise getirilen ve apendektomi yapılan hastalarda gaitada gizli kan, intestinal parazitlerin tür ve prevelansını ileriye yönelik olarak taramaktır.

GEREÇ VE YÖNTEM: Haziran 2009 ile Aralık 20I4 tarihleri arasında apendektomi geçiren I3 yaş üstü I36 hasta ileriye yönelik olarak ve tüm hastaların histopatolojik analiz verileri geriye dönük olarak değerlendirildi.

BULGULAR: Apendektomi sonrası histopatolojik incelemede, hastaların \%75.5 ( $\mathrm{n=103)}$ akut apandisit (AA), \%।3.2'si negatif apandisit (normal appendiks, NA) ( $n=18), \% \mid I . I(n=15)$ perfore apandisit (PA) idi. Ameliyat öncesi gaita analizinde, tüm hastaların \%25'inde ( $n=34)$ intestinal parazitlerin var olduğu, \%।4.7'sinde $(n=20)$ gaitada gizli kanın pozitif olduğu görüldü. Akut apandisit olgularının \%9.7'sinde ( $n=\mid 0)$, PA olgularının \%53.3'ünde $(n=8)$ ve NA olgularının \% I I. I'inde $(n=2)$ gaitada gizli kan pozitifliği tespit edildi ve PA olgularındaki gaitada gizli kan pozitifliği anlamlı derecede yüksek idi $(p<0.00 I)$.

TARTIŞMA: Gaitada intestinal parazitler, apandisit ile ilişkili olmayabilir fakat apandisitin patolojik bulgularına sıklıkla yol açarlar. Gaitada gizli kan pozitifliği apandisit perforasyonu için önemli bir kanıt olabilir.

Anahtar sözcükler: Apandisit; gaita analizi; gaitada gizli kan; intestinal parazitler.

Ulus Travma Acil Cerrahi Derg 20I6;22(5):47I-476 doi: 10.5505/tjtes.20I6.83883 